\title{
The Role Of Integration In Teaching Foreign Languages In Medical Institutes
}

\author{
Anvarov Alijon Uktamovich \\ Teacher Of The Department Of "Uzbek And Foreign Languages" Of The Fergana Medical Institute \\ Of Public Health, Tashkent, Uzbekistan
}

Journal Website:

http://usajournalshub.c

om/index,php/tajssei

Copyright: Original content from this work may be used under the terms of the creative commons attributes 4.0 licence.

\section{ABSTRACT}

This article presents examples and suggestions for the integration of foreign language science taught in medical universities, along with special sciences and Latin classes, which will help medical students in the future to become mature and comprehensively educated. Integrating the disciplines, it opens up a wide path for students to understand the meaning of terms widely used in medicine in foreign languages, as well as to discuss with employees of mature medical institutions around the world the symptoms of diseases, methods of their treatment, books published in foreign languages, articles in the field of medicine without difficulties.

\section{KEYWORDS}

Integration, component, equivalent, methods, mandatory, various, function, conclude, aspect.

\section{INTRODUCTION}

In the pedagogical process, integration is understood as one of the development processes associated with the unification of different parts into a single whole. The essence of the integration process is the qualitative transformation within each element of the 
system. The problems of integration in pedagogy are considered in various aspects in the works of many researchers, such as $\mathrm{V}$. V. Kraevsky, A.V. Petrovsky.[1, 2]

In the works of great teachers, attention is also paid to the integration of pedagogy with other disciplines.

Currently, Uzbekistan is also intensively implementing integration processes in the field of education.

In medical universities, the principle of integration is carried out taking into account the content of education, the definition of its forms and methods, the development of goalsetting, taking into account the interdependence of all components of the educational process, all elements of the system and the relationship between systems.

Everyone knows that it is now important to know foreign languages at a time when relations with other countries in all sectors are developing day by day. A modern person should know at least one foreign language well, because mutual understanding between peoples is of great importance for the further development of his professional knowledge. Without knowledge of foreign languages, such cooperation is almost impossible.

\section{MATERIALS AND METHODS}

As in other spheres of society, the importance of perfect teaching of a foreign language is increasing in medical universities. The study of a foreign language for students is a mandatory component of the professional training of a specialist. Knowledge of a foreign language allows a future medical professional to improve their professional skills, as well as to increase their level of knowledge. Currently, knowledge of foreign languages allows you to study various medical literature, websites, articles, discoveries in the field of medicine, research works in foreign languages. Also participation in international conferences, congresses; continuation and practice of the next stage of study abroad; exchange of experience and knowledge with foreign colleagues.

In medical universities, students are developed in accordance with the study of foreign languages, the directions of their training, the development of educational programs in accordance with their future professions, the development of a number of topics in accordance with the topics of the program, developed in subjects in which their deepening will help students to master a foreign language.

For example, if in a foreign language course there is an explanation on the topic "Excretory system", but this topic is not covered by the plan of the subject "histology", and the student has no idea about the terms related to the topic in his native language, about the performance of activities, the functions of these members, then the student can not sufficiently understand this topic.

\section{RESULTS AND DISCUSSION}

Based on my personal work experience, I must say that before explaining the topic indicated in the plan in a foreign language to the students I teach, I will spend a few minutes talking about the topic in their native languages about the topic "histology" or specialty subjects, and how well they know this theme. 
I introduce the Uzbek equivalents of terms related to the subject, and only then will I try to explain the topic in a foreign language, relying on visualizations or making a presentation.

It is well known that most of the terminology related to medicine originated from Latin and Greek, and it is very important that the curriculum "Latin" and the teaching program "Foreign language" are proportionally structured in teaching and mastering foreign languages by students. That is, if the terms, names of organs, information about their functions are given in the lessons of the "Latin language" and the student remembers these terms and names of organs in Latin, then they can master a foreign language without any difficulties [3].

\section{CONCLUSION}

For example, words related to parts of the body - (lat.) abdomen Venter (ing) - abdomen, (lat.) pelvis (ing) pelvis, words related to the musculoskeletal system, (lat.) sceleton (ing) skeleton, (lat.) vertebra (ing) vertebra, (lat.) musculus muscle (ing), words related to the digestive system (lat.) pharynx (ing) pharynx, (lat.) esophagus (ing) esophagus, (lat.) duodenum (ing) duodenum, (lat.) pancreas (ing) pancreas, (lat.), larynx (ing) larynx, (lat.) Pharinx (ing) Pharinx, (lat.) esophagus (ing) esophagus, (lat.) trachea (ing) trachea, (lat.) bronch (ing) bronchus, (lat.) pleura (ing) pleura, words related to excretory system, (lat.) Ureter (ing) ureter, (lat.) Urethra (ing) Urethra and other words can be an example of this [4].

Based on the above, it can be concluded that in teaching foreign languages to students of medical educational institutions, high results can be achieved only when the topics of classes in the specialty, Latin language and foreign language are conducted in harmony with each other.

\section{REFERENCES}

1. Crayevskiy V. V. Methodology of pedagogical sciences.- Moscow.,2000.

2. Petrovskiy A. V. Bases of pedagogy and psychology of high school. - Moscow, 1986.

3. Chernyavskiy M.N. Latin and bases of medical terminology. Textbook for students of medical institutes. Moscow «Shiko» 2007.

4. Misselius V. Russian-Latin dictionary. Moscow «List New» 2003. 